\title{
The hormonal and metabolic response to stress in the neonate*
}

\author{
David J. Schmeling1, and Arnold G. Coran'2 \\ ${ }^{1}$ University of Michigan Hospitals, Ann Arbor, Michigan, USA \\ ${ }^{2}$ Section of Pediatric Surgery, University of Michigan Medical School. C. S. Mott Children's Hospital, Ann Arbor, MI 48109-0245, USA
}

\section{Introduction}

Postoperative or posttraumatic morbidity and mortality in high-risk adult patients have been correlated with and may be precipitated by the magnitude and duration of the endocrine and metabolic response to the stressful event. Specifically, complications such as severe weight loss, cardiopulmonary insufficiency, thromboembolic disorders, gastric stress ulcers, impaired immunologic function, prolonged convalescence, and death have been related to aspects of the hormonal and metabolic response to surgical or traumatic stress $[86,103]$.

These hormonal and metabolic responses to stress in adults have been the subject of laboratory and clinical investigation for the past century, however similar responses in newborn infants are not as well documented. The aim of this paper is to review the available literature concerning hormonal and metabolic responses to stress in human neonates in order to present a concise, complete, and up-to-date compilation of current knowledge for all those caring for infants subjected to surgery and trauma. Metabolic complications or aberrations induced by stress may upset the delicate metabolic balance of a neonate already involved in the process of adaptation to its postnatal environment. In addition, the normal neonatal nutrient reserves are limited and the energy-consuming processes of rapid growth and maturation occur simultaneously with the additional demands produced by an operation. This difference is borne out by experimental data, which demonstrate a higher morbidity and mortality in neonates than in older children or adults subjected to similar procedures [108, 114]. For these reasons, knowledge of specific aspects of the neonatal stress response may be of greater importance in comparison to similar responses in the adult in an otherwise stable environment, and is imperative for those providing care to these infants.

\footnotetext{
* From the Section of Pediatric Surgery, C. S. Mott Children's Hospital and University of Michigan Medical School
}

\section{The endocrine response to surgery}

Suits and Bottsford outlined a neuroendocrine reflex that is set in motion by significant stress; components of this reflex include an afferent arc consisting of stimuli that initiate the metabolic responses and an efferent arc that leads to volume restoration and energy-substrate production [138]. The sequence is initiated by surgical stress, which affects the neuroendocrine reflex directly through a neural signal to the CNS and indirectly through the elaboration of catecholamines, the major mediators of the hypermetabolic response, and adrenocorticoids, major augmentors of this response. Components of the afferent arc involved in such a system are nociceptors, chemoreceptors, and baroreceptors, all of which are capable of sending signals to the hypothalamus where they become integrated into the physiologic response seen in the stress state.

The efferent arc is described as originating in the hypothalamus, with efferent limbs traveling through the brain stem autonomic regions and the pituitary. These brain stem autonomic areas then send efferent fibers via the parasympathetic and sympathetic nervous systems to the periphery, affecting neuromuscular junctions in the circulatory system and receptors at end-organs, which stimulate the release of peripheral hormones. The pituitary response leads to increased adrenocorticotrophic hormone (ACTH), vasopressin $(\mathrm{ADH})$, growth hormone, and prolactin release.

Neonates have well-developed neural pathways for pain; in fact, the density of nociceptive nerve endings in the skin of newborns is at least equivalent to that in adult skin. These receptors have been noted to be present throughout fetal cutaneous and mucosal surfaces by the 20th week of gestation [143]. Thus, the initial component of the proposed afferent arc develops early in fetal development and the capacity for initiating a stress response is present.

\section{Endorphins}

Endorphins have received attention for their role in initiating the adult postsurgical stress response [48, 35, 97]. 
These substances may act through hypothalamic receptors to initiate a sympathetic nervous system response, resulting in catecholamine secretion [144]. Another of the major effects of the opioid substances liberated during the stress response may be to act as modulators of immune-responsiveness in the stress state. Experimental evidence using a variety of opioid compounds in in-vitro systems of lymphocyte and neutrophil function have demonstrated that either stress-mediated endogenous or exogenous opioids are capable of altering neutrophil and lymphocyte function, thus altering host immune defenses [46].

The role of immunological mediators in posttraumatic stress responses was supported in a recent study by Michie et al., which demonstrated that infusion of the macrophagederived cytokine, tumor necrosis factor (TNF), was capable of initiating a significant stress response in otherwise healthy humans [100]. Hormonal alterations such as elevated $\mathrm{ACTH}$ and, subsequently, cortisol levels were marked and were attributed to TNF's ability to directly influence the release of pituitary hormone as well as stress hormones. TNF has been heralded by Beutler and Cerami as a general mediator of inflammatory and catabolic processes, capable of effecting stress responses from the hypothalamus and adrenal cortex [22]. The role of TNF in mediating the neonatal or adult response to the stresses induced by operation is unknown, but it is conceivable that this may be yet another important mediator in the postoperative response and that endogenous endorphins may modulate the response.

Increased beta-endorphin and ACTH levels have been documented in cord blood at the time of delivery, which clearly produces a significant physiological stress $[12$, 161]. These substances have been shown to be elevated in neonatal blood following periods of stress $[75,76]$ and in amniotic fluid during periods of fetal distress [65]. Altered beta-endorphin levels have also been demonstrated in neonatal septic shock and have been considered to play a significant role in this state [63]. Perioperative changes of endorphin levels in neonates have not been investigated.

\section{Pituitary hormones}

Anterior and posterior pituitary hormones including ACTH, growth hormone, and arginine $\mathrm{ADH}$ are liberated in the adult stress response $[45,64,80,106]$. No perioperative data for neonates have been reported. Boix-Ocha et al., however, recently published a study examining the cortisol response to operative stress in neonates and the response to exogenously administered ACTH [24]. He demonstrated significant increases in cortisol levels following $\mathrm{ACTH}$ administration and noted that this response was similar to the cortisol increases noted in postoperative neonates, providing indirect evidence for a role of pituitary-derived $\mathrm{ACTH}$ in the response to operative stress by the neonate.

\section{Catecholamines}

Studies in adult patients have repeatedly documented substantial rises in serum epinephrine and norepinephrine levels in response to operative or traumatic stress $[59,71$, $79,150]$. Many authors feel these substances are responsible for the initiation of the stress-related catabolic response. Studies investigating catecholamine responses in neonates are also numerous. Nakai and Yamada in 1978 studied catecholamine secretion in normal neonates and neonates subjected to the stress of birth asphyxia (Apgar $5-7$ ) [105]. They demonstrated significant (approximately twofold) rises in epinephrine and norepinephrine levels after in a normal birth. In addition, a further significant increase in norepinephrine (twofold) was noted following asphyxial although no additional significant rise in epinephrine concentration was noted. They attributed these rises to responses by the adrenal medulla and sympathetic nervous system to the combined stresses of labor and asphyxia. They concluded that norepinephrine was the dominant amine secreted by fetal and neonatal chromaffin tissue during stress and postulated that the extramedullary chromaffin tissues (sympathetic nervous system) of the fetus play a significant role in this response.

Anand et al. have reported extensively on fetal metabolic and hormonal responses to operative stress and anesthetic management and have published several studies on the catecholamine response to surgery $[7,8,9]$. In 1985 , they reported their studies on various metabolic and hormonal parameters in neonates undergogin surgery and correlated these findings with a quantitative measure of the amount of stress encountered in the form of a surgical stress score [8]. A highly significant increase in plasma epinephrine and norepinephrine concentrations was documented at the end of surgery.

A subsequent study again demonstrated significant increases in plasma epinephrine and norepinephrine concentrations by the end of an operation, but by $6 \mathrm{~h}$ postoperatively these levels had returned to preoperative values in both term and pre-term infants [7]. The pattern of change in norepinephrine levels was similar to that in adult patients, but the increases in epinephrine levels during surgery contrasted with the data available from adult subjects, in whom epinephrine levels may fall or remain unchanged during surgery and rise only during the postoperative period. These findings were confirmed in a study documenting a significant rise in plasma epinephrine concentrations during patient ductus arteriosus (PDA) ligation; however, this response was abolished by fentanyl anesthesia [9].

In another study comparing anesthetic techniques with or without halothane, the most prominent difference in the hormonal responses between the halothane and nonhalothane groups was the changes in catecholamine concentrations during operation [10]. Neonates in the group that received unsupplemented nitrous oxide (without halothane) showed changes in epinephrine and norepinephrine concentrations that were two to three times greater than the changes seen in the group receiving halothane [10]. The ability to ablate these stress-related responses by either halothane or fentanyl anesthesia suggests that these reactions are initiated by nociceptive stimuli during surgery.

The metabolic effects of these hormonal changes are multiple. Epinephrine not only stimulates hepatic glucose production and causes a sustained decrease in peripheral 
glucose utilization, it also stimulates glucagon secretion and suppresses the release of insulin. Arteriovenous catheterization in adult patients has demonstrated that the release of epinephrine during surgery causes increased production of lactate and pyruvate through glycogenolysis in skeletal muscle [120].

\section{Pancreatic hormones}

Of the numerous hormones secreted by the endocrine pancreas, glucagon and insulin have received the most attention with regard to postsurgical and posttraumatic metabolic regulation. Numerous studies have demonstrated correlations of levels of these hormones with serum glucose and epinephrine concentrations.

\section{Insulin}

In 1966, Ross demonstrated significant decreases in adult plasma insulin levels intraoperatively, with elevated levels in the postoperative period [104]. Curiously, these patients demonstrated decreased glucose tolerance in spite of their elevated insulin levels.

Anand and Aynsley-Green have examined the insulin response to operative stress extensively in human neonates and have documented no significant changes in the plasma insulin levels of pre-term neonates undergoing PDA ligation [5]. They did, however, note a significant decrease in the molar insulin/glucose ratio at the end of surgery that was due to significant increases in blood glucose. The total lack of insulin secretion in response to postsurgical hyperglycemia may be due to either a decreased responsiveness of beta cells in the premature pancreas, which has been documented previously, or a direct inhibition of insulin secretion by the epinephrine that is released during surgery $[111,115]$.

In a subsequent study by this group, again no significant alteration in insulin levels was documented by the end of surgery in a group of neonates [7]. There were, however, significant elevations in insulin concentrations by 6,12 , and $24 \mathrm{~h}$ postoperatively in term neonates, similar to the adult response. Pre-term neonates, in contrast, had insulin levels that remained unchanged during the postoperative period. The authors again postulated that this may be due to decreased responsiveness of beta cells in the premature pancreas and "may explain the tendency of preterm neonates to develop a greater hyperglycemia than term neonates during and after surgery." The total lack of an insulin response in pre-term neonates may result not only in unopposed catabolism during the postoperative period, but through the development of greater hyperglycemia may also precipitate a rapid increase in plasma osmolality during surgery.

Support for the inhibitory effect of catecholamines on insulin secretion was provided in a 1987 study of pre-term infants undergoing PDA ligation with or without fentanyl [9]. The fentanyl-treated infants had a diminished catecholamine response and an increased insulin/glucagon ratio relative to the non-fentanyl group.

\section{Glucagon}

Numerous experimental studies in animals and in adult humans have demonstrated significant elevations in plasma glucagon concentrations in the postoperative period $[21,79,121,126,159]$. Experimentally, infusion of glucagon leads to an increase in glucose production that is potentiated by epinephrine infusion and sustained for prolonged periods by cortisol [51]. In addition, glucagon acts on skeletal muscle to cause amino acid mobilization, ultimately releasing three carbon amino acids (primarily alanine) that stimulate gluconeogenesis, increase urea production, replenish hepatic cell mass, and lead to the production of acute-phase reactant glycoproteins [163].

Few comprehensive data exist regarding the role of glucagon in the postoperative stress response of neonates. Three studies from Anand et al. demonstrated no significant alteration in plasma glucagon levels during or soon after surgery; however, by $24 \mathrm{~h}$ postoperatively a significant decrease from preoperative values had occurred in term neonates, in contrast to the above-mentioned adult studies where elevations were noted $[130,132,156]$. There were strong positive correlations between blood glucose and plasma glucagon levels at $6 \mathrm{~h}$ postoperatively. The significance of the difference in neonatal glucagon response is unknown. Anand et al. pointed out that they studied only a small $(\mathrm{n}=7)$ number of patients and suggested that further confirmatory studies and examinations of the mechanism and implications of this decrease are needed [7].

\section{Adrenocortical hormones}

Adrenocorticoids, initially considered to be the major mediators of the posttraumatic metabolic response, are currently thought to play a permissive or subsidiary role [159].

The major contribution of glucocorticoids on postoperative metabolic changes may concern substrate production. Cortisol acts directly on adipose tissue to cause lipolysis and the release of free fatty acids (FFA) [159]. In addition, through mobilization of amino acids from skeletal muscle, stimulation of glucagon production, and augmentation of catecholamine-induced hepatic glycolysis, cortisol also influences the hyperglycemic state.

It is well established that glucocorticoid hormones, primarily cortisol, are crucial in the metabolic response to surgical stress in the adult, modulating the breakdown of proteins and leading to the release of gluconeogenic amino acids from skeletal muscle. Solomon et al. contributed a landmark article concerning steroid biosynthesis and metabolism in the fetus and placenta in 1959 [130]. Unfortunately, our understanding of the adrenocortical response to operative stress neonates has progressed little since these early studies. Anand et al. demonstrated that the adrenocor-tical responses of premature babies were characterized by diminished secretion of the final products of steroid biosynthesis and increased secretion o the precursor steroid hormones [9]. This was attributed to immaturity of the steroid biosynthetic process as outlined by Solomon et al. [130]. 


\section{Cortisol}

Circumcision is an operation frequently performed during the neonatal period. Physiologic as well as behavioral effects of circumcision have become the subject of numerous recent studies [69, 132, 141, 156, 157]. These studies have demonstrated that the neonate is capable of a significant cortisol response to the stress induced by circumcision as early as in the first $6 \mathrm{~h}$ of life. The fact that these data paralleled the response to exogenous ACTH administration by earlier investigators [74] led to the conclusion that the circumcision-induced response is likely secondary to endogenous ACTH production and that an intact hypothalamicpituitary axis does exist and is capable of generating a stress response in these young infants. The ability to block the cortisol response using the technique of dorsal nerve block suggests that the cortisol response noted with circumcision is mediated at least in part through afferent nerve pathways [90].

A more detailed look at adrenocortical responses was outlined in a recent article by Boix-Ocha involving a 7-year study of infants and neonates undergoing operative or chemical (ACTH administration) stress [24]. A number of significant observations were noted: (1) neonates did not have the normal adult circadian cycle of plasma cortisol levels (this difference was postulated to be secondary to neuroendocrinological immaturity); (2) the cortisol response to surgical or biochemical (ACTH) stress was agedependent, with neonates mounting a quantitatively lesser response than infants; and (3) neonates less than 9 days of age had a more rapid response yet released significantly lower amounts of cortisol following surgical stress.

A number of interesting observations have thus been made and a few qualitative and quantitative differences between children and adults have been noted, indicating the need for further study in this area.

\section{Aldosterone}

In adult patients undergoing major surgical procedures, plasma aldosterone concentrations have been found to increase within minutes following surgery and to remain elevated for up to $24 \mathrm{~h}$ post-surgery [34]. Enquist et al. found that the aldosterone response to surgery could be inhibited by intravenous saline given during the surgical procedure [56]. These authors proposed that infusion of saline inhibits the renin release seen during surgery and thus decreases the aldosterone response.

No data regarding the aldosterone response in postoperative neonates were found in our review of the literature.

\section{Growth hormone}

Growth hormone release has been observed in adults subjected to operative stress, and the quantity released was proportional to the degree of stress [166].

Ward et al., in a recent study, demonstrated that administration of growth hormone following gastrointestinal sur- gery in adult patients resulted in a postoperative protein synthesis rate $209 \%$ higher than in controls [149]. The protein breakdown rate was $170 \%$ higher than in controls, and the net relative increase in synthesis to breakdown increased by $39 \%$. They suggested that growth hormone administration could improve the efficiency of protein metabolism after surgery. In addition to the observation of diminished protein oxidation, these investigators demonstrated increased fat oxidation in patients receiving growth hormone, which is consistent with other studies that have documented the capacity of growth hormone to increase lipolysis and FFA oxidation [92].

The growth hormone response to neonatal operative stress has received little attention, with only one study having recently demonstrated a postoperative rise in the level of growth hormone following open-heart surgery in infants [102].

\section{Renin-angiotensin system}

Adult patients have been demonstrated to produce a threefold increase in plasma renin activity following surgery [119]. These changes in plasma renin activity have been found to be clearly correlated with blood pressure changes during surgery [15]. This appears to be a transient phenomenon, with a return to normal renin levels shortly after surgery [29].

No studies detailing the plasma renin response to operative stress in newborns were discovered during our search of the literature; however, an increase has been observed to follow the stress of venipuncture in a group of full-term neonates [60]. A significant increase in plasma renin activity was noted within $5 \mathrm{~min}$ after venipuncture with a return to basal levels $60 \mathrm{~min}$ thereafter. These findings are somewhat difficult to interpret, as there were no significant changes in plasma levels of cortisol, epinephrine, or norepinephrine following venipuncture. As has been outlined in earlier sections, these hormones have been consistently demonstrated to be increased following operative stress in other newbom studies. It is possible that renin responses may be triggered by a degree of stress lower than the threshold required to induce the release of catecholamines or cortisol, although this seems unlikely. Certainly this area is ripe for further study.

\section{Antidiuretic hormone}

No data regarding the actual measurement of the ADH response in the stressed situation was found in either the adult or the pediatric literature. However, recent studies by Coran and Drongowski measuring total body water and extracellular fluid volume in postoperative neonates suggest that water retention occurs in the early postoperative period in newborns [39], and ADH has been postulated to be involved in this process. 


\section{Thyroid hormones}

Finley and others have demonstrated that operative trauma results in a fall in adult serum active tri-iodothyronine and a rise in inactive tri-iodothyronine (reverse T3) levels [59, $27,113]$. No data specifically concerning changes in thyroid hormones in postoperative neonates are available.

In conclusion, the endocrine response of adult patients to operative and nonoperative trauma is characterized mainly by a substantial increase in circulating concentrations of the catabolic hormones and a decrease in plasma concentrations of the global anabolic hormone, insulin. The magnitude and duration of this response, particularly with respect to changes in the plasma concentrations of cortisol, catecholamines, glucagon, growth hormone, and ADH appears to be proportional to the extent o the surgical injury. In addition, changes in the blood concentrations of some of these hormones may be prolonged in patients with postoperative complications. It has been documented that these hormonal changes may have profound effects on metabolic homeostasis, circulatory hemodynamics, immunocompetence, renal homeostasis, and gastrointestinal physiology as well as having behavioral and psychological effects on patients undergoing surgery. The adjustments in fuel metabolism during and after stress resulting from these hormonal changes will be discussed in the following section.

The neonatal hormonal response to stress is much less well characterized. it is predominantly catabolic, with documented elevations of catecholamines and endorphins. The alterations in glucagon and insulin levels in neonates do not parallel the adult data. Cortisol responsiveness is also diminished in comparison with data from the adult literature, and this difference may be maturation-dependent. In short, there are many areas of the hormonal response to operative and nonoperative stress that have not been thoroughly investigated in the neonatal age group.

\section{The metabolic response to surgery}

Considerable data have accumulated characterizing the metabolic response of adults to surgery and trauma. A great deal less is known about the metabolic effects produced in neonates by major operative and nonoperative stress. Metabolic studies, even on normal infants, are few due to limitations caused by insensitive assays, difficulties inherent in conducting prolonged observations, and the limited amount of blood that can be withdrawn ethically. It is apparent that postoperative treatment would be greatly improved if a thorough understanding of the metabolic consequences of stress were achieved. The evidence suggests that neonates frequently respond to trauma and stress in a manner different from that of adults or older children.

Adult patients show an increase in oxygen consumption $\left(\mathrm{VO}_{2}\right)$ after trauma or operation following a brief "ebb" period of depressed metabolic rate [42, 43]. In a study in postoperative neonates, Ito et al. demonstrated that the $\mathrm{VO}_{2}$ of a full-term, normally-fed, nonoperated neonate increases with advancing age until approximately the 2nd or $3 \mathrm{rd}$ week of life [82]. These einvestigators demonstrated that some postoperative newborns, predominantly those undergoing major abdominal operations, manifest a lower postoperative $\mathrm{VO}_{2}$ than would be expected for their age and size. They concluded that postoperative $\mathrm{VO}_{2}$ in neonates is better correlated with caloric intake than with the intensity of the operative stress, in striking contrast to the increased metabolic-rate findings in adults.

\section{Carbohydrate metabolism}

Adult postoperative changes in carbohydrate metabolism can be summarized as a significant hyperglycemic response both during and after surgery. This effect may be the result of both an increase in glucose production and a diminution in peripheral glucose utilization, with a relative decrease in insulin concentrations $[3,30,93,101,120,136$, $150,160,167]$.

Pioneering work early in this century by Benedict and Talbot, who monitored the respiratory quotients (RQ) of normal newborn babies, demonstrated that as much as $80 \%$ of the energy requirement is fulfilled by calories derived from fat [17]. This is interesting in light of the fact that carbohydrates provide the main source of energy in the fetus. However, soon after birth and even before feeding is started, a rapid fall in glycogen reserves has been shown [127]. In addition, blood glucose concentrations are also known to fall in the early postnatal period [40]. An increase in plasma FFA and ketone bodies has been shown to occur concurrent with these changes in glucose and glycogen, adding support to the importance of fat-derived calories in the newborn as he/she changes his/her major metabolic foodstuff $[107,110]$.

Unfortunately, operations on neonates are frequently accompanied by periods of starvation that may be prolonged, especially if the gastrointestinal tract is involved. The advent of hyperalimentation has aided somewhat in altering this pattern Depot fat accounts for $10 \%-15 \%$ of the body weight of the normal human neonate, and, as stated above, this may provide the main source of energy during the period of starvation soon after birth $[77,151]$.

\section{Glucose}

In 1968, intravenous glucose tolerance tests were performed on 14 newborn babies being operated upon for abnormalities of the alimentary tract [54]. The authors observed that 6 of these 14 infants had a greatly reduced tolerance to glucose administered by i.v. infusion. They noted a constant rate of glucose disappearance that was unrelated to the absolute glucose concentration, in contrast to data in older children and adults, whose rate of disappearance varies with the rate of administration. Elphick and Wilkinson postulated as explanations for these observations that: (1) babies may be less able than adults to form glycogen from glucose; (2) there may be temporary increased insulin dependence in the newborn; and (3) the uptake of glucose by the tissues may be reduced by high circulating concentrations of substances such as epinephrine and growth hormone. They concluded that the prolonged use of parenteral glucose solutions might in some cases lead to severe hyper- 
glycemia and that there is marked variability between infants in their capacity to handle infused glucose.

Elphick and Wilkinson also demonstrated a postoperative increase in blood glucose concentrations to approximately twice the preoperative levels in newborns, but

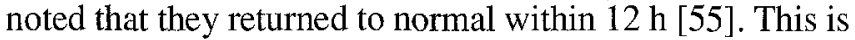
in contrast to data from adult surgical patients, where blood. glucose levels may remain high for several days. These authors noted the similarity of their findings to those of Pinter [111] and proposed that the elevation in blood glucose noted in the postoperative period may be due to either increased production or decreased utilization of glucose or a combination of the two.

In evaluating starvation, a condition that is frequently linked with operative stress in newborns, Elphick and Wilkinson were unable to document hypoglycemia in normal-birth-weight infants starved for up to 1 week [55]. They postulated that the glucose-sparing action of FFA was responsible and suggested a relationship between maintenance of normal blood sugar during starvation and body fat stores.

The human fetus is dependent upon the mother for its glucose needs, and no glucose production has been demonstrated during intrauterine life [84]. There is, however, a potential for fetal gluconeogenesis: the presence of key gluconeogenic enzymes in fetal liver specimens has been documented [95]. In a study utilizing stable carbon isotopes, Kalahan et al. examined glucose turnover, systemic glucose production rate, and recycling of glucose carbon as an indicator of gluconeogenesis [85] in six normal newborn infants ranging in age from $2 \mathrm{~h}$ to 3 days. During the perinatal period, when the placental or maternal supply of substrate, including glucose, is abruptly interrupted, the newborn demonstrates a normal capacity for systemic glucose production in order to meet its metabolic needs. These studies, however, suggest that the source of the available glucose is chiefly from the process of glycogenolysis rather than gluconeogenesis. This predominant role of glycogenolysis over gluconeogenesis may be the result of the ready availability of sufficient glycogen stores due to the frequent feeding of neonates. It is not difficult to imagine that this system may be interfered with by the stresses placed on an infant by operation and interruption of dietary intake as well as by alterations in gastrointestinal function. Unfortunately, similar stable isotope studies to elucidate stress-induced changes in postoperative glucose heomeostatic mechanisms in neonates are nonexistent.

The available evidence in adult patients suggests that increased glucose production from the splanchnic tissues may contribute substantially to the hyperglycemic response to surgical stress. The studies showing altered glucose tolerance [54], however, also suggest a role for decreased glucose utilization in this state. The hyperglycemic response is, in all likelihood, complex and multifactorial. Both the ability to utilize glucose in peripheral tissues in an impaired state and the mechanism of utilization may be altered with shifts in the balance of energy derived from aerobic and anaerobic metabolism.

Thus, although the precise mechanism of the hyperglycemic response is not clear, the clinical implications of significant hyperglycemia in a neonate are important. Sig- nificant changes in plasma osmolality can result from alterations in glucose levels. It has been documented in newborns that an increase in plasma osmolality of greater than $25 \mathrm{mosmol} / \mathrm{kg}$ over a period of $4 \mathrm{~h}$ can have profound detrimental effects on the renal cortex and cerebral cortex and may even precipitate intracranial hemorrhage $[13,58]$.

\section{Pyruvate, lactate, alanine}

In addition to the marked postoperative hyperglycemia, a number of investigators have demonstrated increases in blood lactate and pyruvate concentrations in postoperative adult patients [20, 147]. Arteriovenous catheterization studies in adults have demonstrated that epinephrine release during surgery increases lactate and pyruvate production as a result of glycogen breakdown in peripheral tissues [120]. In addition, it is well known that injured tissues surrounding the surgical wound derive their energy mainly from glycolysis and that this may contribute to the increased lactate production after surgery [81, 160].

Other factors involved in the increased lactate levels include tissue hypoperfusion and hypoxia during operation [160]. These changes may be related to anesthesia or may be secondary to hypotension as a result of excessive blood loss or altered circulatory patterns during surgery [31].

In their 1987 study of the effects of fentanyl on postoperative metabolic changes in neonates, Anand et al. demonstrated increased in blood lactate and pyruvate concentrations during surgery in the non-fentanyl group but noted no similar changes in the fentanyl-treated patients [9]. Twenty-four hours postoperatively blood lactate and pyruvate values had fallen below preoperative levels in the non-fentanyl group of infants. Quantitative blood levels of total gluconeogenic substrates (measured as the sum of the blood concentrations of lactate, pyruvate, alanine, and glycerol) in the non-fentanyl group also increased substantially during surgery but fell by $24 \mathrm{~h}$ postoperatively. These changes in the postoperative period were attributed to utilization of these substrates for gluconeogenesis with excess glucose production in the non-fentanyl neonates. The differences between the fentanyl and non-fentanyl groups were postulated to be due to blunting of the stress-induced catecholamine response in the fentanyl group, with resultant diminution of catecholamine-induced postoperative changes.

An earlier study from Anand's group provides support for this concept [8]. Significant increases in blood concentrations of lactate, pyruvate, total ketone bodies (acetoacetate and hydroxybutyrate), and glycerol were noted during surgery in their experimental group, which consisted of both term and pre-term neonates. In this study the levels of blood lactate remained elevated until $12 \mathrm{~h}$ after surgery, whereas all other metabolites measured returned to preoperative levels by $6 \mathrm{~h}$ postoperatively. Levels of blood lactate showed a high degree of correlation with plasma epinephrine concentrations at the end of and $6 \mathrm{~h}$ after surgery. There was also a significant correlation between blood glycerol levels and plasma epinephrine and norepinephrine at the end of surgery. In summarizing their observations, these investigators suggested that the impor- 
tance of the changes noted in their study may be the provision of substrates for hepatic gluconeogenesis in the postoperative period. The significant hyperlactatemia noted during surgery in the premature infants was postulated to be due to deficiency of the key hepatic gluconeogenic enzymes, although separate studies by Kalahan et al. and Marsac et al. do not support this hypothesis [84, 95].

It is conceivable that the greater degree of hyperlactatemia in pre-term neonates may be related to less rich glycogen stores in their sekeletal muscles in comparison with term neonates, with resultant increased dependence on glycogenolysis for substrate provision in the face of an immature gluconeogenic mechanism. However, the rise in blood lactate levels may also be due to tissue hypoxia caused by changes in the peripheral circulation during anesthesia and surgery.

The significance of serum concentrations of the gluconeogenic amino acid alanine in newborns is much less clear. Although alanine is known to be the key gluconeogenic amino acid in adults, some studies have documented hypoalaninemia in newborn infants receiving glucagon $[57,116]$. This effect was postulated to be secondary to increased splanchnic utilization of alanine for glucagonstimulated gluconeogenesis. In a subsequent study of the relationships of neonatal plasma levels of alanine, glucagon, and insulin [44], however, no correlation was observed between changes in alanine and glucose concentrations, further clouding the role of gluconeogenic substrates and the process of gluconeogenesis in the hyperglycemic response.

\section{Protein metabolism}

Acute malnutrition as a result of insufficient nutrient intake or the increased metabolic demands of illness or trauma leads to increased catabolism of muscle protein and a negative nitrogen balance. These changes, along with rapid utilization of energy substrate stores at a time when nutritional intake is often reduced, drastically affect the ability to heal wounds, combat infection, and have sufficient muscular strength to breathe adequately, all resulting in increased morbidity and mortality [137]. Even the wellnourished patient may experience periods of debility after the injury of major surgery, which may relate to the reduction of protein reserves and energy stores [33].

Major operative stress in adult patients results in a negative nitrogen balance resulting from increased protein breakdown and decreased protein synthesis in extrahepatic tissues. In addition, there is increased utilization of amino acids for alternate purposes such as gluconeogenesis, synthesis of acute-phase reactants by the liver, and synthesis of components $o$ the healing process in injured tissues. Patients experiencing trauma or sepsis have been demonstrated to have rapid onset of muscle wasting, protein depletion, and elevated urea excretion [41, 49]. The adult response to starvation is characterized by sacrifice of visceral protein to furnish amino acids as needed for gluconeogenesis and other purposes, whereas in stressful situations such as trauma or sepsis, muscle protein is degraded and the liver increases its protein content [122]. As important as this metabolic response may be to survival, prolonged mobilization of amino acids leads to devastating muscle weakness. Depletion of protein is also accompanied by deterioration of cellular structure, insufficient production of acute-phase reactants, and reduced synthesis of other necessary proteins. Under such conditions patients are prone to die from overwhelming infection culminating in multisystem faialure [98].

The sick infant is particularly susceptible to the adverse metabolic effects that a major illness or surgical operation may impose. Perioperative protein metabolic and nutritional status must be given special consideration in this population due to the smaller body size, rapid growth, highly variable fluid requirements, and immaturity of certain organ systems. These factors, plus low caloric reserves in the premature infant and sick child, make adequate caloric and amino acid intake particularly important. Consequently, the infant whose nutritional needs are not met as a result of a functional or organic disorder of the gastrointestinal tract can rapidly develop protein-calorie malnutrition and associated complications [38].

The most important clinical consequence of a catabolic stress reaction is felt to be increased protein breakdown after surgery [16]. The consequences, as outlined above, could be particularly deleterious in a postoperative neonate whose nutritional status is already tenuous.

Colle et al., in a 1959 study of postoperative infants, demonstrated urinary nitrogen losses of $200-300 \mathrm{mg} / \mathrm{kg}$ per day in contrast to $80 \mathrm{mg} / \mathrm{kg}$ in normal infants [36, 72]. These losses were, however, transient and not sustained.

In an elaborate study of muscle protein degradation in nonoperated premature infants, Ballard et al. examined correlations between energy input, nitrogen retention, weight gain, and subsequent survival [16]. They demonstrated that approximately $5 \%$ of total muscle protein was degraded daily. In addition, the total and fractional rates of protein breakdown showed significant reverse correlations with nitrogen retention but had no relationship to total energy input. Protein degradation was also higher in infants who died within 2 weeks of the study. It was unclear whether this increased degradation in preterminal infants was related to events that stimulated muscle proteolysis, such as sepsis, or was due to the underlying nitrogen status of the patients [148]. The authors were unable to demonstrate any correlation between energy input in the premature infants and rates of muscle protein breakdown, in contrast to large increases in total muscle protein breakdown seen in rats subjected to total energy restriction and a slight decrease in muscle protein breakdown during longterm fasting in obese adult humans [94, 108]. They attempted to explain the differences between their results and those of other studies on the basis of the size of the fat reserves, since there is evidence that ketonemia produced by fat mobilization is accompanied by a lower rate of muscle protein breakdown. Since the premature infant clearly has very little adipose tissue, this may explain the difference [117]. The increased protein breakdown may result from a demand for amino acids that cannot be met simply by a decrease in protein synthesis.

The ratio of muscle protein degradation to total-body protein degradation was found to be $7 \%$, in contrast to a 
value of $30 \%$ in adults. This difference was attributable to the very small pool of muscle protein in premature infants [142]. In addition, to account for the tissue sites of the remaining $93 \%$ of protein degradation in premature infants they postulated that organs that comprise greater relative ratios of neonatal body weight such as brain, liver, or skin may contribute significantly to total-body protein degradation, stating that this visceral protein catabolic response observed "is surely catastrophic if prolonged for any length of time, thus arguing forcibly that a substantial nitrogen supply to the premature infants should be maintained."

Duffy and Pencharz studied the effects of postoperative amino acid intake on urinary nitrogen losses and wholebody protein synthesis in 18 neonates [50]. They concluded that a nitrogen intake of about $450 \mathrm{mg} / \mathrm{kg}$ per day should meet the needs of a neonate in the immdiate postoperative period. This is higher than the data of Zlotkin suggest [169]. Duffy and Pencharz also documented an improved nitrogen balance (the relationship between nitrogen intake and nitrogen retention) in association with increased nitrogen intake. This improved balance was attributed to a reduction in the fraction of amino-nitrogen flux coming from the breakdown of endogenous protein. They were unable to demonstrate any increase in skeletal muscle breakdown postoperatively in the infants studied by measuring urinary creatinine and 3-methyl histidine excretion. Finally, this group was able to show postoperative nitrogen accretion, even during the 3 days immediately post-surgery, but noted that nitrogen utilization may be partially impaired postoperatively. On the basis of these studies, they recommended a nitrogen intake of $450 \mathrm{mg} / \mathrm{kg}$ per day with a non-protein energy intake of $85-90 \mathrm{kcal} / \mathrm{kg}$ per day.

Winthrop et al., in a prospective evaluation of pediatric trauma patients, demonstrated significant increases in basal metabolic rate (BMR), whole-body protein turnover, protein synthesis, and urinary nitrogen excretion [162]. These patients had a negative nitrogen balance due to the fact that protein breakdown increased relatively more than protein synthesis. The increase in protein breakdown/turnover, synthesis, and nitrogen excretion greatly exceeded the increase noted in BMR $(93 \%, 82 \%$, and $56 \%$ vs. $14 \%$ increase in BMR) in these young (less tan 10 years old) post-trauma patients. They were unable to demonstrate a correlation between BMR and whole-body protein turnover, suggesting that changes in energy expenditure and protein metabolism following injury may be mediated by different mechanisms. They concluded that the metabolic response of pediatric patients to multiple trauma differs from that of adults and noted that pediatric trauma patients need not only increased caloric intake, but, more importantly, a significant increase in protein intake in order to optimize the balance between protein synthesis and breakdown. Thus, the differences from adults include a much smaller change in total energy expenditure in children and a lack of correlation between increased metabolic rate and whole-body protein turnover.

In addition to being indicators of increased proteolytic activity or altered protein metabolism, there may be a functional role for any alterations in plasma amino acid patterns following stress. For example, it has been suggested that arginine may have an immunoregulatory effect as well as promoting nitrogen retention and wound healing [17]. Arginine may be important because of its effects augmenting immune-responsiveness and diminishing protein catabolism [123, 129]; it is also known to stimulate secretion of pituitary and pancreatic hormones $[18,104]$. Any of these roles may be important in the postoperative stressed state, yet they have not been throughly investigated in postoperative newborns.

Studies of postoperative nitrogen balance in term neonates originate with Rickham in 1957. Since that time, several investigators have substantiated a strongly negative nitrogen balance in response to surgical stress and have demonstrated that this may persist for 72-96 $\mathrm{h}[36,78,91$, $118,152]$. These studies have demonstrated that the severity of surgical stress correlates with the degree of nitrogen loss. In addition, it has been noted that postoperativ nitrogen loss is greater in the neonatal age group than in older infants subjected to similar degrees of surgical stress $[68,139]$. In a recent study of neonates undergoing either major or minor operative procedures, a direct relationship was noted between the degree of stress and the quantity of nitrogen loss [67].

In a recent study, different levels of amino acid intake were evaluated with regard to nitrogen retention, ratios of whole-body amino acid nitrogen flux, and protein synthesis and breakdown ratios in 18 infants during the $72 \mathrm{~h}$ immediately following surgery [50]. One group of intants received $2.3 \pm 0.4 \mathrm{~g}$ amino acid/ $\mathrm{kg}$ per day and the other $3.9 \pm 0.5 \mathrm{~g} / \mathrm{kg}$ per day. They showed no differences in amino acid flux or synthesis and breakdown of protein. However, the group receiving the higher amino acid intake had significantly greater net protein-synthesis ratios. The improved nitrogen utilization in this group was achieved principally by a reduction in endogenous protein breakdown. There were no differences between the two groups in urinary creatinine or 3-methyl histidine (3MH) excretion. Since these two parameters reflect skeletal muscle protein turnover, the differences between groups in nitrogen retention and protein turnover appear to be mediated by visceral protein sparing.

$3 \mathrm{MH}$ serves as a marker for endogenous skeletal muscle actin and myosin breakdown. The $3 \mathrm{MH}$ : creatinine $(3 \mathrm{MH}: \mathrm{Cr})$ ratio has been found to correlate closely with net nitrogen balance in pre-term and term neonates $[4,32$, $83,168]$. Pre-term neonates stressed by severe clinical illnes causing a negative nitrogen balance and weight loss have demonstrated a maredly elevated $3 \mathrm{MH}: \mathrm{Cr}$ ratio [125]. Additional studies in postoperative term [4] and pre-term [9] neonates have demonstrated a significant increase in the $3 \mathrm{MH}: \mathrm{Cr}$ ratio and in nitrogen loss in the first $72 \mathrm{~h}$ after surgery [4]. Reduction of the surgical stress responses in pre-term and term neonates by altering anesthetic techniques such as halothane or fentanyl supplementation was found to inhibit these changes in urinary $3 \mathrm{MH}: \mathrm{Cr}$ ratio $[9,11]$.

From the adult studies outlined, it can be concluded that the negative nitrogen balance seen following moderate surgical stress is mainly due to a decrease in the rate of protein synthesis, while the rate of protein breakdown is unaltered or slightly increased. However, protein metabolism in patients exposed to severe degrees of surgery, 
trauma, or sepsis is characterized by a massive breakdown of tissue proteins, with protein synthesis rates being unaltered, decreased, or in some cases slightly increased.

It is in this latter group of critically ill patients that the therapeutic manipulation of protein metabolism may provide the greatest clinical benefit in terms of reduction of morbidity and mortality. The neonatal surgical data indicate a higher degree of muscle protein degradation than seen in adults, resulting in a strongly negative nitrogen balance in the postoperative period. It appears that the provision of adequate amounts of amino acids, either enterally or parenterally, is capable of at least partially ablating this degradation of endogenous protein.

\section{Fat metabolism}

In adult patients the postoperative state produces a catabolic response that, in addition to the already mentioned changes in carbohydrate and protein metabolism, also results in mobilization of non-essterified fatty acids (NEFA) from adipose tissues and increased formation of ketone bodies. These changes may be of prime importance in providing an endogenous energy source in the posttraumatic state.

Two decades ago, Allison et al. documented increased plasma concentrations of NEFA associated with decreased glucose tolerance in a group of patients suffering from burn injuries [1]. Subsequent studies in postoperative patients by the same group also demonstrated an increase in plasma NEFA [2] both preoperatively and intraoperatively. The preoperative increase was attributed to the catabolic stimulus provided by the emotional stress of anticipating an operation. An increase in NEFA following trauma was confirmed in 1974; the extent of the response correlated with the severity of the trauma [99].

The importance of the contribution of fat to energy supply in a stressed state was illustrated by Kinney et al. in a 1970 study in which they demonstrated, by indirect calorimetry, that as much as $75 \%-90 \%$ of postoperative energy requirements were supplied by fat metabolism and the remainder was provided by protein [89]. it may be necessary for these NEFA to undergo conversion by the liver to ketone bodies prior to their utilization as an energy source [154].

Lipolysis of stored triglycerides and control of adipocyte lipolysis are important in mobilization of lipids in the injured patient. Lipolysis in the adipocyte is carried out by the enzyme hormone-sensitive lipase (HSL) [135]. This enzyme complex (HSL) is affected by a number of other circuclating hormones, including catecholamines.

Wolfe, in a study of patients suffering from severe burn injury in which he utilized stable isotope tracers, demonstrated changes in the substrate cycle involving the simultaneous breakdown and synthesis of stored triglycerides (triglyceride-fatty acid cycle) [164]. The rates of triglyceride-fatty acid and glycolytic-gluconeogenic cycling were elevated in these patients by $450 \%$ and $250 \%$, respectively. These investigators concluded that increased substrate cycling contributes to the increased thermogenesis and energy expenditure seen in severe burns and that increased triglyceride-fatty acid cycling is due to beta-adrenergic stimulation. Therefore, the increased metabolic rate observed may be secondary to increased substrate cycling and not solely to increased rates of protein synthesis [165].

Because the stress response associated with surgery causes elevation of plasma NEFA and decreased insulin secretion, one would expect an increased production of ketone bodies in response to operative stress. However, several studies have shown that the levels range from no change or mild elevation to a substantial increase $[37,62$, $87,109]$. It has been demonstrated that patients who remain normoketonemic after major surgery are likely to manifest increased nitrogen loss in comparison with patients who are hyperketonemic postoperatively [117]. Studies in trauma patients suggest that the lack of ketogenesis is due to postinjury ADH release, the degree of which is directly proportional to the severity of injury $[154$, 158]. Therefore, ADH may exacerbate protein catabolism and muscle wasting by suppressing ketogenesis in patients subjected to severe trauma, major surgical stress, or sepsis.

In the human baby, depot fat accounts for $10 \%-15 \%$ of body weight [151]. From metabolic balance data, Hughes et al. calculated that only about $8 \%$ of body protein was catabolized when a 3-kg neonate was starved for 12 days, yet 39\% of the baby's fat was used up [77]. Glycerol released from adipose tissue during lipolysis could be a source for supplementation or maintenance of blood glucose levels.

Anand et al. demonstrated an increase in blood levels of total ketone bodies and glycerol during surgery in neonates [8]. They believed this increase was a reflection of catecholamine-stimulated lipolysis and ketogenesis. They noted a strong correlation between serum levels of glycerol, epinephrine, and norepinephrine at the end of an operation. In addition to their sue as an energy source, they postulated that the ketone bodies in peripheral tissues, through formation of citrate and inhibition of phosphofructokinase, may also further inhibit peripheral utilization of glucose and contribute to the postoperative hyperglycemia seen in neonates $[5,155]$. In a study of the effectiveness of improved anesthetic management with the use of halothane, this group demonstrated that concentrations of ketone bodies increased during surgery in the group not receiving halothane but were unchanged in the group receiving halothane, with a significant difference at the end of the operation [11]. Plasma concentrations of NEFA were significantly higher in the group not receiving halothane than in the other group at the end of and $6 \mathrm{~h}$ after operation. These responses indicate a greater degree of lipolysis, probably mediated by release of catecholamines and facilitated by the decrease in the ratio of insulin to glucagon during surgery, in the group that did not receive halothane. In addition, halothane supresses the catecholamine response, which results in decreased lipolysis and decreased formation of NEFA.

Anand et al. postulate that the primary sources of energy in the surgical neonate are provided by mobilization of NEFA from adipose tissue and their conversion to ketone bodies in liver cells. Fat metabolism in surgical neonates and infants has, however, received little study. Pinter reported a substantial increase in plasma NEFA 
during surgery with a further significant increase postoperatively, whereas Elphick and Wilkinson found to significant changes in the perioperative period $[39,55,111]$. In the latter study a decrease in plasma triglycerides was documented postoperatively, whereas the plasma concentrations of lipoproteins, phospholipids, and cholesterol were unchanged during and after surgery. These responses could be at least partially altered by starvation since the neonates in both the above studies received no nutritional support for variable periods before and during the study. Recent studies in term neonates have shown that circulating concentrations of NEFA, glycerol, and total ketone bodies increased significantly during surgery but had reverted to preoperative values by $6 \mathrm{~h}$ postoperatively [8]. The significant increase in FFA, glycerol, and total ketone bodies during surgery is indicative of lipolysis and ketogenesis mediated by intraoperative catecholamine release, as evidenced by the strong correlation between blood glycerol concentrations and plasma epinephrine and norepinephrine levels at the end of surgery. An earlier study in older infants undergoing inguinal herniorrhaphy documented a significant increase in plasma NEFA during surgery and concluded that this was indicative of lipolysis in response to the stress induced by surgery [140].

In addition to serving as an energy source, studies of glycerol turnover in newborn infants have shown that $75 \%$ of the glycerol formed from lipolysis enters the gluconeogenic pathway in the neonatal liver and contributes to $5 \%$ of hepatic glucose production [25]. The oxidation of FFA by the neonatal liver may further stimulate postoperative gluconeogenesis through the generation of ATP, the production of acetyl-CoA, which activates pyruvate carboxylase, and the provision of reducing equivalents for glyceraldehyde-3-phosphate dehydrogenase [153].

In a study of PDA ligation in term and pre-term infants, there was a significant rise in blood levels of lactate, pyruvate, total ketone bodies, and glycerol by the end of the operative procedures, but by $6 \mathrm{~h}$ postoperatively all these metabolites had reverted to their preoperative levels [5].

In nonoperated newborn babies who have not yet been fed, the respiratory quotinent and blood glucose level fall while the serum concentration of FFA rises, indicating a rapid change from carbohydrate to fat metabolism soon after birth [54]. In addition, liver and muscle glycogen reserves are reduced and the rate of disappearance of glucose administered by i. $v$. infusion is decreased [14, 26, 40, $73,128]$. It also appears that protein is less easily utilized for energy purposes during starvation at this time $[70,96]$. All these findings indicate that fat, rather than protein or carbohydrate, is being used for energy production in the newborn.

Pinter, in a study of 29 newborns being operated upon for congenital anomalies, described their metabolic characteristics between the 1 st and 7 th postoperative day [112]. In these investigations, a decreased FFA level was observed between the 2 nd and 7 th days whereas during the operation and on the 1st postoperative day a well-defined increase in FFA level took place that might have been caused by the response to the anesthetic and surgery (increased release of catecholamines and steroids, metabolic effects of anesthetics, hypoxia, hypothermia, acidosis, etc.). Although the
FFA level showed a tendency to decrease postoperatively, it still remained higher than the preoperative value. This pattern of fat metabolism can be explained by two facts: (1) in the postoperative period the complex hormonal and metabolic changes evoked by surgery are returning to preoperative levels; and (2) the state of hypoalimentation. These combined hormonal and metabolic processes, which are also typical of the adaptation to extrauterine life, explain why it is difficult to find a reciprocal relationship between glucose and FFA metabolism [47, 115]. Elphick also failed to demonstrate a relationship between glucose and FFA levels in newborn infants following surgery [53].

Studies in adults have indicated that the concentration of circulating FFA varies in response to surgical stress [146]. Talbert et al's study examined infants undergoing bilateral inguinal hernia repair [140]. Eleven of 13 patients demonstrated a significant elevation in FFA levels following surgery. The plasma FFA have been identified as the major metabolite from the mobilization of body adipose tissue/depot fat to be used as an energy source $[47,66]$. The hydrolysis of triglycerides is the major biochemical reaction in fat stores for the production of energy precursors. Mobilization of fatty acids is mediated by three central mechanisms: metabolic, hormonal, and neural [134]. Under conditions of starvation a net release of FFA from the peripheral fat depots is observed. Various hormones have been demonstrated to be active in the regulation of fatty acid mobilization [145]; among the most important of these hormonal regulators are the catecholamines, which are potent stimulants of FFA mobilization [133]. concomitant increases in the rate of glycerol production verify the fact that elevations in plasma FFA are due to an absolute increase in the rate of hydrolysis of triglycerides. The importance of the innervation of fat stores in facilitating FFA mobilization has been verified by experiments with innervated and denervated tissues [134]. The sympathetic nervous system is a critical component of this process. Since norepinephrine is the chemical mediator at the postganglionic sympathetic nerve ending, the final mechanism of action may be similar to that observed following the parenteral administration of this compound. The importance of this system as a mechanism for mobilizing FFA has been documented in adults during emotional stress [23]. It is evident that circulating levels of FFA are regulated by a variety of factors, many of which also participate in the infant's response to stress. The importance of this composite action is suggested in Talbert's experiments, in which he demonstrated an increase in plasma FFA in the absence of a discernible increase in circulating catecholamines. Previous investigators have found an elevation of FFA in adults following cholecystectomy and inguinal herniorrhaphy [146]. These results substantiate the sensitivity of FFA mobilization to the stimulus of surgical trauma and suggest the usefulness of the plasma FFA level as an index of the infant's stress response.

In addition to the outlined mobilization of body fat stores, renewal of these stores has been suggested. Winthrop et al. showed that body fat increased postoperatively from day 0 to day 7 from $12.9-0.6 \%$ to $14-0.6 \%$ $(P<0.05)$ in 13 full-term infants undergoing surgery at approximately 10 days of life [162]. Although this is a 
small but statistically significant increase in body fat, the magnitude of the change falls within the range of experimental error for anthropometry. In this study fat accounted for almost $60 \%$ of the new solid tissue synthesiszed, which is in agreement with Fomon et al.'s figure of 56.6\% [61].

\section{Conclusions}

It is apparent that adult patients demonstrate a catabolic response to the stresses induced by operative or accidental trauma. It seems that the degree of this catabolic response may be quantitatively related to the extent of the trauma or the magnitude of associated complications such as infection. The host response to infection, traumatic injury, or major operative stress is characterized by such events as fever, pituitary and stress hormone elaboration, mineral redistribution, and increased acute-phase protein synthesis [21].

The beneficial effects of this stress response consist in providing alternate energy sources to meet metabolic demands and essential building blocks for synthetic activities occuring in the postoperative period. It has been suggested that the hyperglycemic response is essential for supplying the increased glucose requirements of injured tissue [81]. In addition, the proteolytic component of the stress response provides the necessary amino acid elements for reparative protein synthesis and production of acutephase reactants by the liver. The changes in metabolic patterns induced by the stress response are satisfied in part by increased lipolysis and ketogenesis to provide an alternate source of metabolic fuel for tissues such as the brain and skeletal muscle. Additionally, the observed gluconeogenesis may aid in maintaining the glucose supply for vital organs principally dependent on glucose $[52,160]$.

This metabolic response has also been shown to potentiate many adverse conditions in the postoperative period and to further exacerbate the stress response. Examples include a hypermetabolic state with attendant increased $\mathrm{VO}_{2}$, increased energy requirements, increased temperature, elevated cardiac output, and altered or impaired inflammatory or immune-responsiveness. Numerous investigators have demonstrated that adult patients exposed to severe degrees of traumatic stress are subjected to greatly increased rates of complications such as cardiac or pulmonary insufficiency, myocardial infarction, impaired hepatic and/or renal function, gastric stress ulcers, and sepsis. Furthermore, evidence exists to suggest that this response may be life-threatening if the induced catabolic activity remains excessive or unchecked for a prolonged period. Moyer et al. were able to identify with a great degree of certainty the patients who were likely to die based on a single analysis of a variety of plasma-borne substrates obtained up to 9 days prior to death [103].

It is apparent that modulating or blunting the catabolic response induced by the stress state may have beneficial effects. In studies of postoperative pain management, improved pain control resulted in reduction of postoperative nitrogen loss and shortened periods of convalescence following operation $[28,88]$.
It is evident from this review that human newborns, even those born prematurely, are capable of mounting an endocrine and metabolic response to operative stress. Unfortunately, many of the areas for which a relatively wellcharacterized response exists in adults are poorly documented in neonates. As is the case in adults, the response seems to be primarily catabolic in nature because the combined hormonal changes include an increased release of catabolic hormones such as catecholamines, glucagon, and corticosteroids coupled with suppression of and peripheral resistance to the effects of the primary anabolic hormone, insulin.

The catecholamines may be the agents of primary importance in this response, and thus may modulate the remaining components of the hormonal response to stress as well as the metabolic changes, including inhibition of insulin release, marked hyperglycemia, and breakdown of the neonate's stores of nutrients (carbohydrate, protein, and fat). These reactions ultimately result in the release of glucose, NEFA, ketone bodies, and amino acids. Although these metabolic by-products are necessary to meet the body's altered energy needs in a time of increased metabolic demands, it is not difficult to imagine that a severe or prolonged response would be very detrimental to a previously ill neonate with limited reserves of nutrients and already high metabolic demands imposed by rapid growth, organ maturation, and adaptation to the postnatal environment. Preliminary investigations by Anand et al. outlined in this review indicate that alterations in anesthetic technique with the addition of agents such as halothane and fentanyl may be able to significantly blunt this catabolic response. In addition, it appears that modulation of the immune response may also greatly affect the postoperative catabolic response. It is hopeful that future developments and the acquisition of more detailed knowledge o the response will allow us to modify the stress response in neonates in order to further decrease their mortality and morbidity.

\section{References}

1. Allison SP, Hinton P, Chamberlain MJ (1968) Intravenous glucose tolerance, insulin and free fatty acid evels in burned patients. Lancet II: 1113

2. Allison SP, Tomlin PJ, Chamberlain MJ (1969) Some effects of anaesthesia and surgery on carbohydrate and fat metabolism. Br J Anaesthesia 41: 588

3. Alberti KGMM, Batstone GF, Foster KJ, Johnston DG (1980) Relative role of various hormones mediating the metabolic response to injury. J Parent Ent Nutr 4: 141

4. Anand KJS (1985) Metabolic and Endocrine Effects of Surgery and Anesthesia in the Human Newborn Infant. D Phil Thesis, University of Oxford

5. Anand KJS, Aynsley-Green A (1985) Metabolic and endocrine effects of surgical ligation of patent ductus arteriosus in the human preterm neonate: Are there implications for further improvement of postoperative outcome? Mod Probl Paediatr 23: 143

6. Anand KJS, Hickey PR (1987) Pain and its effects in the human neonate and fetus. New Engl J Med 317: 1321

7. Anand KJS, Brown MJ, Bloom SR, Aynsley-Green A (1985) Studies on the hormonal regulation of fuel metabolism in the human 
newborn infant undergoing anesthesia and surgery. Hormone Res 22: 115

8. Anand KJS, Brown MJ, Causon RC, Christofides ND, Bloom SR, Aynsley-Green A (1985) Can the human neonate mount an endocrine and metabolic response to surgery? J Ped Surg 20:41

9. Anand KJS, Sippell WG, Aynsley-Green A (1987) Randomised trial of fentanyl anaesthesia in preterm babies undergoing surgery: Effects on the stress response. The Lancet 8527: 243

10. Anand KJS, Sippel WG, Schofield NM, Aynsley-Green A (1988) Does halothane anaesthesia decrease the metabolic and endocrine stress responses of newborn infants undergoing operation? Br Med J 296: 668

11. Anand KJS, Sippell WG, Schofield NM, Aynsley-Green (1988) Does Halothane Anaesthesia Decrease the Metabolic and Endocrine Stress Response of Newborn Infants Undergoing Operation? Br Med J 296: 668

12. Arai K, Yanaihara T, Okinaga S (1976) Adrenocorticotropic hormone in human fetal blood at delivery. Am J Obstet Gynecol 125: 1136

13. Arant BS, Gooch WM (1978) Effects of acute hyperglycemia on the central nervous system of neonatal puppies. Pediatr Res 12: 549

14. Baird JD, Farquhar JW (1962) Insulin-secreting capacity in newborn infants of normal and diabetic women. lancet 1:71

15. Bailey DR, Miller ED, Kaplan JA, Rogers PW (1975) The reninangiotensin aldosterone system during cardiac surgery with morphine-nitrous oxide anesthesia. Anesthesiol 42: 538

16. Ballard FJ, Tomas FM, Pope LM, Hendry PG, James BE, MacMahon RA (1979) Muscle protein degradation in premature human infants. Clin Sci 57: 535

17. Barbul A (1986) Arginine: Biochemistry, physiology and therapeutic implications. JPEN 10: 227

18. Barbul A, Rettura G, Levenson MS, Barbul A, Returra G, Levenson SM, Seifter E (1983) Wound healing and thymotropic effects of arginine: A pituitary mechanism of action. Am J Clin Nutr 37: 786

19. Benedict FG, Talbot FB (1915) The physiology of the newborn infant. Character and amount of the catabolism. Carnegie Inst Pub No. 233, Washington

20. Bent JM, Paterson JL, Mashiter K, Hall GM (1984) Effects of high-dose fentanyl anesthesia on the established metabolic and endocrine response to surgery. Anesthesia 39:19

21. Bessey PQ, Watters JM, Aoki TT, Wilmore DW (1984) Combined hormonal infusion stimulates the metabolic response to injnjury. Ann Surg 200: 264

22. Beutler B, Cerami A (1987) Cachectin: More than a tumor necrosis factor. New Engl J Med 316: 379

23. Bogdonoff MD, Estes EH, Trout D (1959) Acute effect of physiologic stimuli upon plasma nonesterified fatty acid level. Proc Soc Exper Biol Med 100: 503

24. Boix-Ocha J, Martinez Ibanez V, Potau N, Lloret J (1987) cortisol response to surgical stress in neonates. Pediatr Surg Int 2: 267

25. Bougneres PF, Karl IE, Hillman LS, Bier DM (1982) Lipid transport in the human newborn: Palmitate and glycerol turnover and the contribution of glycerol to neonatal hepatic glucose output. J Clin Invest 70: 262

26. Bowie MD, Mulligan PB, Schwartz R (1963) Intravenous glucose tolrance in the normal newborn infant: The effects of a double dose of glucose and insulin. Pediatrics, Springfield 31:590

27. Brandt M, Kehlet H, Skovsted L, Hansen JM (1976) Rapid decrease in plasma triodothyronine during surgery and epidural analgesia independent of afferent neurogenic stimuli and of cortisol. Lancet 2: 1333

28. Brandt MR, Fernandez A, Mordhurst R, Kehlet H (1978) Epidural analgesia improves postoperative nitrogen balance. $\mathrm{Br}$ Med $\mathrm{J} 1$ : 1106

29. Brandt MR, Olgaard K, Kehlet H (1979) Epidural analgesia inhibits the renin and aldosterone response to surgery. Acta Anesth Scand 23: 267

30. Bromage PR, Shibata HR, Willoughby HW (1971) Influence of prolonged epidural blockade on blood sugar and cortisol response to operations upon the upper part of the abdomen and thorax. Surg Gynecol Obstet 132: 1051
31. Bunker JP (1962) metabolic acidosis during anesthesia and surgery. Anesthesiol 23: 107

32. Burgoyne JL, Ballard FJ, Tomas FM, Dubozy A, MacLennan AH, Fitzgerald A, Dahlenburg AW (1982) Measurements of myofibrillar protein breakdown in newborn human infants. Clin Sci 63: 421

33. Christensen J, Kehlet $\mathrm{H}$ (1984) Postoperative fatigue and changes and nutritional status. Br J Surg 71: 473

34. Cochrane JPS (1978) The aldosterone response to surgery and the relationship of this response to post-operative sodium retention. $\mathrm{Br}$ J Surg 65: 744

35. Cohen MR, Pickar D, Dubois M (1983) Role of the endogenous opioid system in the human stress response. Psychiatr Clin N Amer 6:457

36. Colle, Paulsen (1959) Response of the newborn infant to major surgery. I. Effects on water, electrolyte, and nitrogen balance. Pediatrics 23: 1063

37. Cooper GM, Holdcroft A, Hall GM, Alaghband-Zadeh J (1979) Epidural analgesia and the metabolic response to surgery. Canad Anaesthetic Soc J 26: 381

38. Coran AG (1986) Nutrition of the surgical patient. In: Welch (ed) Pediatric Surgery. Chapter 10, Yearbook Publishers, Fourth ed.

39. Coran AG, Drongowski RA (1989) Body fluid compartment changes following neonatal surgery. J Ped Surg 24: 829

40. Cornblath M, Ganzon AF, Nicolopoulos D, Baens GS, Hollander RJ, Gordon MH, Gordon HH (1961) Studies of carbohydrate metabolism in the newborn infant. III. Some factors influencing the capillary blood sugar and the response to glucagon during the first hours of life. pediatrics 27:378

41. Cuthbertson DP (1930) The disturbance of metabolism produced by bony and nonbony injury, with notes on certain abnormal conditions of bone. Biochem J 24: 1244

42. Cuthbertson DP (1942) Post-shock metabolic response. Lancet 1: 433

43. Cuthbertson DP (1959) Protein metabolism in relation to energy needs. metabolism 8: 787

44. DeLamater PV, Sperling MA, Fiser RH, Phelps D, Oh W, Fisher DA (1974) Plasma alanine: relation to plasma glucose, glucagon and insulin in the neonate. J Pediatrics 85: 702

45. DeMaria EJ, Lilly MP, Gann DS (1987) Potentiated hormonal responses in a model of traumatic injury. J Surg Res 43: 45

46. Deitch EA, Xu D, McIntyreBridges R (1988) Opioids modulate human neutrophil and lymphocyte function: Thermal injury alters plasma B-endorphin levels. Surgery 104: 41

47. Dole VP (1956) A relation between non-esterified fatty acids in plasma and the metabolism of glucose. J Clin Invest 35: 150

48. Dubois M, Pickar D, Cohen M, Roth YF, MacNamara TF, Bunney WE (1981) Surgical stress in humans is accompanied by an increase in plasma B-endorphin immunoreactivity. Life Sci 29: 1249

49. Duke JH, Jorgensen SB, Broell JR, Long CL, Kinney JM (1970) Contribution of protein to caloric expenditure following injury. Surgery 68: 168

50. Duffy B, Pencharz P (1986) The effects of surgery on the nitrogen metabolism of parenterally fed human neonates. ped Res 20:32

51. Eigler N, Sacca L, Sherwin RS (1979) Synergistice interactions of physiologic increments of glucagon, epinephrine and cortisol in the dog. J Clin Invest 63: 114

52. Elliott M, Albert KGMM (1983) The hormonal and metabolic response to surgery and trauma. In: Kleinberger G, Deutsch E (eds) New aspects of clinical nutrition. Karger, Basel, p 247

53. Elphick MC (1972) Some aspects of fat and carbohydrate metabolism in the newborn. PhD Thesis, London

54. Elphick MC, Wilkinson AW (1968) Glucose intolerance in newborn infants undergoing surgery for alimentary tract anomalies Lancet 539

55. Elphick MC, Wilkinson AW (1981) The effects of starvation and surgical injury on the plasma levels of glucose, free fatty acids, and neutral lipids in newborn babies suffering from various congenital anomalies. Ped Res 15: 313

56. Enquist A, Blichert-Toft M, Olgaard K, Brandt MR, Kehlet H (1978) Inhibition of aldosterone response to surgery by saline administration. Brit J Surg 65: 224 
57. Felig P, Pozefsky T, Marliss E, Cahill GF (1970) alanine: key role in gluconeogenesis. Science 167:1003

58. Finberg L (1967) Dangers to infants caused by changes in osmolal concentration. Pediatrics 40: 1031

59. Finley RJ, Inculet RI, Pace R, Holliday R, Rose C, Duff JH, Groves AC, Woolf LI (1986) Major operative trauma increases peripheral amino acid release during the steady-state infusion of total parenteral nutrition in man. Surgery 99: 491

60. Fiselier T, Monnens L, Moerman E, Van Muster P, Jansen M, Peer $P$ (1983) Influence of the stress of venipuncture on basal levels of plasma renin activity in infants and children. Int J Pediatr Nephrol 4: 181

61. Fomon SJ, Haschke F, Zeigler EE, Nelson SE (1982) Body composition of reference children from birth to age 10 years. Am J Clin Nutr 35: 1169

62. Foster KJ, Alberti KGMM, Binder C, Hinks L, Karran SJ, Orskov H, Smythe P, Talbot S, Turnell D (1979) Lipid metabolites and nitrogen balannce after abdominal surgery in man. Br J Surg 66: 242

63. Furman WL, Menke JA, Barson WJ, Miller RR (1984) Continuous naloxone infusion in two neonates with septic shock. J Pediatr 105: 649

64. Gann DS, Lilly MP (1983) The neuroendocrine response to multiple trauma. World J Surg 7: 101

65. Gautray JP, Jolivet A, Vielh JP, Guillemin R (1979) Presence of immunoassayable beta-endorphin in human amniotic fluid: Elevation in cases of etal distress. Am J Obstet Gynecol 129: 211

66. Gordon RS, Cherkes A (1956) Unesterified fatty acid in human blood plasma. J Clin Invest 35: 206

67. Greenwall MJ, Kettlewell MGW, Gough MH (1983) Nitrogen requirements for postoperative parenteral nutrition in neonates. Acta Therapeutica 9:5

68. Grewal RS, Mampilly J, Misra TR (1969) Postoperative protein metabolism and electrolyte changes in pediatric surgery. Int Surg 51:142

69. Gunnar MR, Malone S, Vance G, Fisch RO (1985) Coping with aversive stimulation during the neonatal period: Quiet sleep and plasma cortisol levels during recovery from circumcision. child Devlp 56: 824

70. Hahn P, Kddovsky O (1966) Utilization of nutrients during postnatal development. Oxford, $\mathrm{p} 78$

71. Halter JB, Pflug AE, Porte D (1977) Mechanism of plasma catecholamine increases during surgical stress in man. J Clin Endocrinol Metab 45: 936

72. Hansen JDL, Smith CA (1953) Effects of withholding fluid in the immediate post-natal period. Pediatrics 12: 99

73. Heard CRC, Stewart RJC (1960) Protein malnutrition and disorders of the endocrine glands: Biomchemical changes. Acta Endocrinol Suppl 51: 1277

74. Hillman DA, Giroud CJ (1965) Plasma cortisone and cortisol levels at birth and during the neonatal period. J Clin Endocrinol Metab 25: 243

75. Hindmarsh KW, Sankaran K (1985) Endorphins and the neonate. Can Med Assoc J 132: 331

76. Hindmarsh KW, Sankaran K, Watson VG (1984) Plasma beta-endorphin concentrations in neonates associated with accute stress. Dev Pharmacol Ther 7: 198

77. Hughes EA, Stevens LH, Wilkinson AW (1964) Some aspects of starvation in the newborn baby. Arch Dis Child 39: 598

78. Hughes EA, Stevens LH, Toms DA, Wilkinson AW (1965) Esophageal atresia: Metabolic effects of operation. Br J Surg 52: 403

79. Hulton N, Johnson DJ, Smith RJ, Wilmore DW (1985) Hormonal blockade modifies post-traumatic protein catabolism. J Surg Res 39: 310

80. Hume DM, Egdahl RH (1959) The importance of the brain in the endocrine response to injury. Ann Surg 150: 697

81. Im MJC, Hoopes JE (1970) Energy metabolism in healing skin wounds. J Surg Res 10: 459

82. Ito T, Iyomasa $\mathrm{Y}$, Inoue $\mathrm{T}$ (1976) Changes o the postoperative minimal oxygen consumption of the newborn. J Ped Surg 11: 495
83. Johnston UDA (1964) Endocrine aspects o the metabolic response to surgical operation. Ann R. Coll Surg Eng1 35: 270

84. Kalahan SC, C'Angeleo LJ, Savin S, Adam PAJ (1979) Glucose production in pregnant women at term gestation: Sources of glucose for human fetus. J CLin Investig 63: 388

85. Kalhan SC, Bier DM, Savin SM, Adam PAJ (1980) Estimation of glucose turnover and ${ }^{13} \mathrm{C}$ recycling in the human newborn by simultaneous $\left[1-{ }^{13} \mathrm{C}\right]$ glucose and $\left[6,6-{ }^{2} \mathrm{H}_{2}\right]$ glucose tracers. $\mathrm{J}$ clin $\mathrm{En}-$ docrinol Metab 50: 456

86. Kehlet H (1979) Stress-free anaesthesia and surgery. Acta Anesthes Scand 23: 503

87. Kehlet H, Brandt MR, Hansen AP, Alberti KGMM (1979) Effect of epidural analgesia on metabolic profiles during and after surgery. Brit J Surg 66: 543

88. Kerri-Szanto M (1983) Demand analgesia. Br J Anesthesia 55: 919

89. Kinney JM, Duke JH, Long CL, Gump FE (1970) Tissue fuel and weight loss after injury. J Clin Path 23: 65

90. Kirya C, Ertthmann MW (1978) Neonatal circumcision and penile dorsal nerve blbock: A painless procedure. J Pediatr 96: 998

91. Knutrud $O$ (1965) The water and electrolyte metabolism in the newborn child after major surgery. Scandinavian University Books, Universitetsforlaget, oslo, Norway

92. Kostyo JL, Keagan CR (1976) The biology of growth hormone. Pharmacol Ther 2: 591

93. Kusaka M, Ui M (1977) Activation of the cori cycle by epinephrine. Am J Physiol 232: E145

94. Marliss EB, Murray FT, Nakhooda AF (1978) The metabolic response to hypocaloric protein diets in obese men. J Clin Invest 62 : 468

95. Marsac C, Saudubray JM, Moncion A, Leroux JP (1976) Development of gluconeogenic enzymes in the liver of human newborns. Biol Neonate 28: 317

96. McCance RA, Strangeways WMB (1954) Protein catabolism and oxygen consumption during starvation in infants, young adults and old men. Br J Nutr 8: 21

97. McIntosh TK, Bush HL, Palter M, McIntosh TK, Bush HL, Palter M, Hay JR, Aun F, Yeston NS, Egdahl RH (1985) Prolonged disruption of plasma beta-endorphin dynamics following surgery. J Surg Res 38: 210

98. McMenamy RH, Birkhahn R, Oswald G, Reed R, Rumph C, Vaidyanath N, Yu L, Cerra FB, Sorkness R, Border JR (1981) Multiple systems organ failure: I. The basal state. J Trauma 21: 99

99. Meguid MM, Brannan MF, Aoki TT, Muller Wa, Ball MR, Moore FD (1974) Hormone-subsrate interrelationships following trauma. Arch Surg 109: 776

100. Michie HR, Spriggs DR, Manogue KR, Sherman ML, Revhaug A, O'Dwyer SJ, Arthur K, Dinarello CA, Cerami A, Woiff SM, Kufe DW, Wilmore DW (1988) Tumor necrosis factor and endotoxin induce similar metabolic responses in human beings. Surgery 104: 280

101. Mills NL, Beaudet RL, Isom OW, Spencer FC (1973) Hyperglycaemia during cardiopulmonary bypass. Ann Surg 177: 203

102. Milne EMG, Elliott MJ, Pearson DT, Holden MP, Orskov H, Alberti KGMM (1986) The effect on intermediary metabolism of open-heart surgery with deep hypothermia and circulatory arrest in infants of less than 10 kilograms body weight. Perfusion 1: 29

103. Moyer E, Cerra F, Chenier R, Peters D, Oswald G, Watson F, Yu L, McMenamy RH, Border JR (1981) Multiple systems organ failure. VI. Death predictors in the trauma-septic state- the most critical determinants. J Trauma 21: 862

104. Mulloy AL, Kari FW, Visek WJ (1982) Dietary arginine, insulin secretion, gluccose tolerance and liver lipids during repletion of protein depleted rats. Horm Metab Res 14: 471

105. Nakai T, Yamada R (1978) The secretion of catecholamines in newborn babies with special reference to fetal distress. J Perinat Med 6: 39

106. Newsome HH, Rose JC (1971) The response of adrenocorticotrophic hormone and growth hormone to surgical stress. J Clin Endocrinol 33: 481

107. Novak M, Melichar V, Hahn P, Koldovsky O (1961) Levels of lipids in the blood of newbom infants and the effect of glucose administration. Physiol Bohemoslov 10: 488 
108. Ogata ES, Foung SKH, Holliday MA (1978) The effects of starvation and refeeding on muscle protein synthesis and catabolism in the young rat. Journal of Nutrition 108: 759

109. Oppenheim WL, Williamson DH, Smith R (1980) Early biochemical changes and severity of injury in man. J Trauma 20: 135

110. Persson B, Gentz J (1966) The pattern of blood lipids, glycerol and ketone bodies during the neonatal period, infancy and childhood. Acta Pediatr Scand 55: 353

111. Pinter A (1973) The mtabolic effects of anesthesia and surgery in the newborn infant. Zeitschrift für Kinderchirurgie 12: 149

112. Pinter A (1975) Metabolic changes in newborn infants following surgical operations. Acta Ped Acad Sci Hungary 16: 171

113. Prescott RWG, Yeo PPB, Watson MJ, Johnston PDA, Ratcliffe JG, Everod DC (1979) Total and free thyroid hormone concentrations following elective surgery. J clin Path 32: 321

114. Rackow H, Salanitre E, Green LT (1961) Frequency of cardiac arrest associated with anesthesia in infants and children. Pediatrics 28: 697

115. Randle PJ, Garland PB, Hales CN, Newsholme EA (1963) The glucose fatty-acid cycle: its role in insulin sensitivity and the metabolic disturbances of diabetes mellitus. Lancet 1: 785

116. Reisner SH, Aranda JV, Colle E, Parageorgiou A, Schiff D, Scriver CR, Stern L (1973) The effect of intravenous glucagon on plasma amino acids in the newborn. Pediatr Res 7: 184

117. Rich AJ, Wright PD (1979) Ketosis and nitrogen excretion in undernourished surgical patients. JPEN 3: 350

118. Rickham PP (1957) The metabolic response to neonatal surgery. Harvard University Press, Cambridge, MA

119. Robertson D, Michelakis AM (1972) Effect of anesthesia and surgery on plasma renin activity in man. J Clin Endocrinol Metab 34: 831

120. Ross H, Johnston IDA, Welborn TA, Wright AD (1966) Effect of abdominal operation on glucose tolerance and serum levels of insulin, growth hormone and hydrocortisone. Lancet 2: 563

121. Russel RCG, Walker CJ, Bloom SR (1975) Hyperglucagonaemia in the surgicl patient. Br Med J 1: 10

122. Ryan NT (1976) Metabolic adaptations for energy production during trauma and sepsis. Surg clin North Am 56: 1073

123. Saito H, Trocki O, Wang S, Gonce SJ, Joffe SN, Alexander JW (1987) Metabolic and immune effects of dietary arginine supplementation after burn. Arch Surg 122: 784

124. Schweiss JF, Pennington DG (1981) Anesthetic management of neonates undergoing pallative operations for congenital heart defects. Clev Clin Quart 48: 153

125. Seashore JH, Huszar G, Davis EM (1981) Urinary 3-methylhistidine/creatinine ratio as a clinical tool: Correlation between 3methylhistidine excretion and metabolic and clinical states in healthy and stressed premature infants. metabolism 30: 959

126. Shamoon H, Hendler R, Sherwin RS (1981) Synergistic interactions among antiinsulin hormones in the pathogenesis of stress hyperglycemia in humans. J Clin Endocrinol Metab 52: 1235

127. Sheeley HJ (1961) Glycogen reserves and their changes at birth and in anoxia. Br Med Bull 17: 137

128. Shelley HJ (1964) Carbohydrate reserves in the newborn infant. $\mathrm{Br}$ Med J 1: 273

129. Sitren HS, Fisher H (1977) Nitrogen retention in rats fed on diets enriched with arginine and glycine: I. Improved $\mathrm{N}$ retention after trauma. Br J Nutr 37: 195

130. Solomon S, Bird CE, Ling W, Iwamiya M, Young PCM (1967) formation and metabolism of steroids in the fetus and placenta. Recent Progr Horm Res 23: 297

131. Sperling MA (1982) Integration of fuel homeostasis by insulin and glucagon in the newborn. Mongr Pediatr 16:39

132. Stang HJ, Gunnar MR, Snellman L, Condon LM, Kestenbaum R (1988) Local anesthesia for neonatal circumcision. Effects on distress and cortisol response. JAMA 259: 1507

133. Steinberg D (1963) Fatty acid mobilization- Mechanisms of regulation and metabolic consequences. In: JK Grant (ed) The control of lipid metabolism. Academic Press, New York p 111

134. Steinberg D (1966) Catecholamine stimulation of fat mobilization and its metabolic consequences. Pharmacol Reviews 18: 217
135. Steinberg D, Khoo JC (1977) Hormone sensitive lipase of adipose tissue. Fed Proc 36: 1986

136. Stjernstrom H, Jorfeldt L, Wiklund L (1981) The influence of abdominal surgical trauma upon the turnover of some blood borne metabolites in the human leg. JPEN 5: 207

137. Studley HO (1936) Percentage of weight loss. A basic indicator of surgical risk in patients with chronic peptic ulcer. JAMA 106: 458

138. Suits GS, Bottsford JE jr (1987) The metabolic response to trauma. Resident and Staff Physician 33:21

139. Sukarochano K, Motai Y, Slim M, Shepard R, Kiesewetter WB (1965) Postoperative protein metabolism in Pediatric Surgery. Surg Gynecol Obstet 121: 79

140. Talbert JL, Karmen A, Graystone JE, Haller JA, Cheek DB (1967) Assessment of the infants response to stress. Surgery 61:626

141. Talbert LM, Kraybill EN, Potter HD (1976) Adrenal cortical response to circumcision in the neonate. Obstet Gynecol 48: 208

142. Tomas FM, Ballard FJ, Pope LM (1979) Age dependent changes in the rate of myofibrillar protein degradation in humans as assessed by 3 -methylhistidine and urinative excretion. Clinical Science 56 : 341

143. Valman HB, Pearson JF (1980) What the fetus feels. Br Med J 280 : 233

144. Van Loon GR, Appel NM, Ho D (1981) B-endorphin induced stimulation of central sympathetic outflow: b-endorphin increases plasma concentrations of epinephrine, norepinephrine, and dopamine in rats. Endocrinology 109: 46

145. Vaughan M, Steinberg D (1963) Effect of hormones on lipolysis and esterification of free fatty acids during incubation of adipose tissue in vitro. J Lipid Res 4: 193

146. Wadstrom LB (1959) Plasma lipids and surgical trauma: A methodological, experimental and clinical study. Acta Chir Scand Suppl 238: 1

147. Walsh ES, Traynor C, Paterson JL, Hall GM (1983) Effect of different intraoperative fluid regimenson circulating metabolites and insulin during abdominal surgery. Br J Anaesth 55: 135

148. Wannemacher RW, Dinterman RE (1977) Total body protein catabolism in starved and infected rats. Am J Clin Nutr 30: 1510

149. Ward HC, Halliday S, Sim AJW (1987) Protein nd energy metabolism with biosynthetic human growth after gastrointestinal surgery. Anals of Surg 206: 56

150. Watters JM, Bessey PQ, Dinarello CA, Wolff SM, Wilmore DM (1986) Both inflammatory and endocrine mediators stimulate host response to sepsis. Arch Surg 121: 179

151. Widdowson EM, Spray CM (1951) Chemical development inutero-Arch Dis Child 26: 205

152. Wilkinson AW, Hughes EA, Stevens LH (1965) Neonatal duodenal obstruction. The influence of treatment on the metabolic effects of operation. Br J Surg 52: 410

153. Williamson JR (1976) In Hanson, Mehlman, Gluconeogenesis, its regulation in mammalian species, New York, Wiley p 165

154. Williamson DH (1981) Regulation of ketone body metabolism and the effects of injury. ACTA Chir Scand 52 (Suppl 507): 22

155. Williamson DH (1982) The production and utilization of ketone bodies in the neonate: In Jones (ed) Biochemical development of the fetus and neonate. Amsterdam, Elsevier, p 621

156. Williamson PS, Williamson ML (1983) Physiologic stress reduction by a local anesthetic during newborn circumcision. Pediatrics $71: 36$

157. Williamson PS, Evans ND (1986) Neonatal cortisol response to circumcision with anesthesia. Clin Pediatr 25: 412

158. Williamson DH, Farrell R, Kerr A, Smith R (1977) Muscle-protein catabolism after injury in man, as measured by urinary excretion of 3-methyl histidine. Clin Sci Mol Med 52: 527

159. Wilmore DW (1976) Hormonal responses and their effect on metabolism. Symposium on response to infection and injury II. Surg Clin North Amer 56: 999

160. Wilmore DW (1981) Glucose metabolism following severe injury. J Trauma 21: 705

161. Winters AJ, Oliver C, Colston C, MacDonald PC, Porter JC (1974) Plasma ACTH levels in the human fetus and neonate as related to age and paturition. J Clin Endocrinol Metab 39: 269 
162. Winthrop AL, Jones PJH, Schoeller DA, Filler RM, Heim T (1987) Changes in the body composition of the surgical infant in the early postoperative period. J Ped Surg 22: 546

163. Wolfe BM, Culebras JM, Aoki TT, O'Connor NE, Finley FJ, Kaczowka A, Moore FD (1979) The effect of glucagon on protein metabolism in normal man. Surgery $86: 248$

164. Wolfe RR, Herndon DN, Jahoor F, Miyosji H, Wolfe M (1987) Effect of severe burn injury on substrate cycling by glucose and fatty acids. NEJM 317: 403

165. Wolfe RR, Herndon DN, Peters EJ, Jahoor F, Desai MH, Holland OB (1987) Regulation of lipolysis in severely burned children. Annals Surg 206: 214
166. Wright PD, Johnston IDA (1975) The effects of surgical operation on growth hormone levels in plasma. Surgery 77: 479

167. Wright PD, Henderson K, Johnston IDA (1974) glucose utilization and insulin secretion during surgery in man. Br J Surg 61: 5

168. Young VR, Munro HN (1978) N T-methylhistidine (3-methylhistidine) and muscle protein turnover; an overview. Fed Proc Fed Am Soc Exp Biol 37: 2291

169. Zlotkin SH (1984) Intravenous nitrogen intake requirements in full-term newborns undergoing surgery. Pediatrics 73: 493 